\title{
Meeting Teacher Expectations in a DL Professional Development Programme - A Case Study for Sustained Applied Competence as Programme Outcome
}

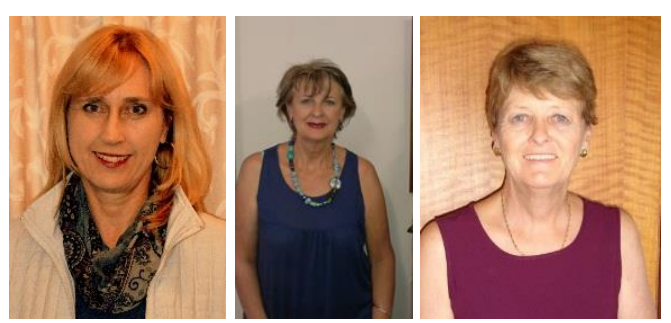

Cornè Gerda Kruger ${ }^{1}$, Ona Janse Van Rensburg ${ }^{2}$, and Marike W De Witt ${ }^{3}$

1,2North-West University, South Africa, ${ }^{3}$ UNISA, South Africa

\begin{abstract}
Meeting teacher expectations for a professional development programme (PDP) is expected to strengthen sustainable applied competence as programme outcome since teachers will be more motivated to apply the programme content in practice. A revised distance learning (DL) programme was augmented by a practical component comprising a work-integrated portfolio and audio-visual material, aimed to support the applied competence of practising teachers in the South African context. An evaluation of the way the programme measured up to teacher expectations was deemed critical for future DL programme design. A qualitative study based on an interpretivist philosophical approach collected data of teacher expectations for and of the practical component through multiple methods. Their contributions were linked with four main themes related to applied competence as identified in the literature. Participant expectations and experiences with regards to each theme were compared by means of electronic coding through ATLASti ${ }^{\mathrm{TM}}$. The findings show a strong correlation between expectations for and experiences of the way the practical component supports the elements of applied competence. Since DL is viewed as a viable and cost effective way to improve teacher competence in developing countries, these findings serve as impetus for further investigation and refining ways to support applied competence in a distance learning professional development programme (DL PDP).
\end{abstract}

Keywords: pedagogical content knowledge, self-directed skills, application of theory in practice, professional teacher attitude, professional development programme, distance learning

\section{Introduction}


Effective teacher educator environments must be created to "support, sustain, and 'tune' the visions, understandings, performances, motivations, and reflections of all its members" (Shulman \& Shulman, 2004, p. 267). We add to this notion by asserting that the environment should also be "in tune" with the expectations held by teachers for their own learning through a professional development programme (PDP). Creating such an environment for the diverse teacher population enrolling for a PDP delivered via distance learning (DL) in the South African context is not easily accomplished. Challenges specifically relate to the way a programme supports improved applied competence.

In order to address these challenges, a work-integrated portfolio and visual resources were added to a professional development programme delivered via DL to Foundation Phase teachers practising in the Northern Cape Province of South Africa. It was anticipated that this model, where teachers are guided in reflection on and in practice as well as in the implementation of work-integrated tasks in practice, would not only support the development of applied competence but also assist in connecting theory to practice and the consequent development of a more reflective practice.

DL programmes are often used for professional development and as initiatives by the Department of Basic Education (DBE) to improve teaching standards in South Africa. We therefore consider the exploration and evaluation of mechanisms such as the portfolio in equipping teachers for practice and motivate professional learning as imperative. Since evaluations of PD programmes mostly focus on teacher experiences and performance as a result of the programme, Schieb and Karabenick (2011), call for a focus on the interrelationships between teacher motivation and participation in a PDP (p. 8). In line with the view of these authors we believe that the findings of such investigations will guide educators and policy makers in aligning PDP goals with teacher expectations and encourage teachers to engage in PDP activities with enthusiasm (Schieb \& Karabenick, 2011, p. 17).

This article specifically reports on the findings of a qualitative investigation as part of a programme implementation evaluation which focussed on teacher expectations for the way a revised PDP will support their applied competence, the way they experienced the programme to have indeed supported their applied competence, and the relationship between their expectations and experiences with regards to the identified core elements of applied competence.

\section{Review of Literature}

The literature confirms the relationship between a teacher's experiences of an education programme and the eventual impact of the programme on classroom practice (Beaudin \& Quick, 1995, p. 18; Dewey, 1938, p. 44; Shulman \& Shulman, 2004, p. 269; Williamson, 2012). Furthermore, Shulman and Shulman (2004) highlight the role of teacher vision in the successful outcomes of teacher education programmes (pp. 257-258). Such visions, which include teachers' expectations of their own development and improvement, serve as motivation for learning: "Discrepancies between one's visions and one's performance can create the motivation to learn - or if too great - can discourage learning and replace hope with despair" (Shulman \& Shulman, 2004, p. 261).

To identify the so-called "discrepancies" between expectations for a programme and improved performance as programme outcome clearly implies an ability by teachers to reflect on the status quo and on the need for improved teaching competence. Where teachers' visions or expectations for the way in which a programme supports them in improving their applied competence concur with their experiences of the way the programme met their envisioned learning needs, it could be a strong 
indication of sustained improved teaching competence as programme outcome. On the other hand, it could also be the case that a programme which does not live up to teacher expectations could have debilitating consequences for improved applied competence as programme outcome.

The incapacity of DL programmes to meet the needs of teachers with regard to their applied competence in the South African context is probably one of the reasons for the criticism levelled against the use of DL for teacher professional development. In his report on an investigation by the National Education Evaluation and Development Unit (NEEDU) into the state of Foundation Phase education in South Africa, Taylor (2013) refers to a "slippage between qualifications and competence" (p. 70). According to Taylor, the application of the same old remedies such as afternoon workshops, add-on programmes by distance, and short courses offered by universities and NGOs have no impact on the standards of education (p. 70).

Various authors share Taylor's concern regarding the incapacity of DL programmes to ensure sustained applied competence and improved practice as programme outcomes (Binns \& Wrightson, 2006, p. 8; Daniel, 2010; Perraton, Creed, \& Robinson, 2002; Rowntree, 1992; Siaciwena, 2007). In developing countries such as South Africa, DL programmes for the professional development of teachers are mostly based on economies of scale. Large numbers of teachers practising in urban, semirural, and deep rural areas enrol for these programmes. The diverse student population, consisting of teachers with varying years of experience who are on different competence levels and from any of the 11 language groups of South Africa, escalates the criticism against implementing such programmes.

A literature investigation showed concurrence regarding the value of the portfolio as a means to support the development of the core elements of applied competence comprising pedagogical content knowledge (Darling-Hammond \& Snyder, 2000, p. 537; Klenowski, Askew, \& Carnell, 2006, p. 278), self-directed skills (Chetcuti, Buhagiar, \& Cardona, 2011, p. 70; Shulman, 2003; Yasin, Rahman, \& Ahmad, 2012, p. 3840), application of theory in practice (Berrill \& Addison, 2010, pp. 1180, 1181; Klenowski, 2002, p. 273; Wray, 2007, p. 1145) and a professional teacher attitude (Farr Darling, 2001, p. 117; Imhof \& Picard, 2009, p. 150). Determining the way the programme/portfolio met teacher expectations with regard to the development of these core elements was deemed indicative of the way teachers will be motivated to implement new knowledge in practice in a sustainable way.

Identifying and defining the core elements of applied competence from the literature was key to our evaluation of the way the revised DL programme component met teacher expectations with regard to support for improved applied competence.

\section{Core Elements of Applied Competence}

The following core elements are highlighted in the literature: the role of pedagogical content knowledge (PCK), a professional attitude, applied practice, and self-directedness (SD) with specific reference to reflection and inquiry as basic SD skills,

The literature emphasises the importance of teacher PCK which includes knowledge of learning content, pedagogical knowledge, and curriculum-specific knowledge as outcomes of an effective teacher education programme (Darling-Hammond, 2010, p. 36; South African Departments of Basic Education and Higher Education and Training, 2011, p. 11; Van Driel \& Berry, 2012, p. 12). Shulman (1987) describes pedagogical content knowledge as the blending of content and pedagogy into an understanding of how particular topics, problems, or issues are organised, represented, and adapted 
to the diverse interests and abilities of learners (p. 8). This view accentuates the interrelatedness between subject and pedagogical knowledge. Shulman's depiction of the transformation of content knowledge through the act of pedagogical reasoning clearly requires self-directedness from teachers through reflection and inquiry.

The relational mental state that directs the behaviours of an individual (Ahmad, Said, Zeb, Sihatullah, \& Ur Rehman, 2013) can be defined as attitude. The relationship between teachers' professional attitudes and their performance in practice is well-documented in the literature (Opfer \& Pedder, 2011, p. 387; Tsai, 2007, p. 239; Vreugdenhil, 2005, p. 2). We strongly agree with Vreugdenhill (2005) who posits that attitude, which includes aspects such as motivation, personal beliefs, commitment, and principles is closely related to teacher behaviour and self-directedness and plays an important role in teacher learning and professional development (p.2).

Grounded in the theory of Dewey (1938), various authors argue that application of theory in practice is important for durable changes in behaviour (Granlund, Berglund, \& Erikson, 2000; Sandberg, Anstett, \& Wahlgren, 2007). When students are exposed to quality teaching environments and have the opportunity to pragmatically link learning content in a meaningful and reflective manner, professional development will be effective (Lobman, Ryan, McLauchlin, \& Ackerman, 2004, p. 32). Teacher education programmes, whether pre-service or PDP, should therefore include opportunity for guided application of theory in practice.

Although self-directedness includes various facets such as self-regulation, goal setting, and life-long learning, two main qualities of self-directedness came to the fore in the analysis of the literature. These qualities firstly relate to reflective behaviour, including reflective learning and the development of a reflective practice (Boud, Keogh, \& Walker, 1996; Dewey, 1933; Schön, 1983). However, reflection without action does not guarantee improved classroom practice. Therefore we view inquiry, which means that teachers react on their self-reflections by pursuing more effective teaching and learning strategies, as the second fundamental component of self-directedness (Kansanen, 2006, p. 12; Stoll, Fink, \& Earl, 2003, pp. 145, 165). Dewey supports the notion that the development of these two selfdirected learning strategies through PDPs will eventually reverberate in the teaching practice of teachers: "It becomes an object of study - that is, of inquiry and reflection - when it figures as a factor to be reckoned with in the completion of a course of events in which one is engaged and by whose outcome one is affected" (Dewey, 1916, p. 158). The central role of motivation in self-directedness and consequently also professional development, lead us to place this disposition at the core of our evaluation study.

\section{The Role of Motivation in Teacher Learning}

Although the literature confirms the role of motivation in teacher learning (Ferlazzo, 2012; Ley, 2005, p. 1; Oolbekkink-Marchand, Van Driel, \& Verloop, 2006, p. 219), motivation as an inextricable part of self-regulated learning is often neglected in programme evaluation. Zimmerman (2002) not only highlights motivation as an important prerequisite for meaningful self-regulated learning, but also for the way in which knowledge will be applied in practice (p.66).

Timperley (2008) points out that adult learners such as teachers participating in a PDP are less likely than school-aged students to engage in new learning experiences if they do not see the relevance to their professional lives (p.12). This view emphasises that PDPs should offer content relevant to 
teachers' classroom practice and their specific learning needs. Should programmes meet teachers' needs it will serve as motivation to engage with new knowledge and to implement new knowledge in practice. Motivation is integral to the learning process, and on-going learning as a programme outcome. Should a PDP further guide teachers in reflective learning of relevant content, applied competence will be supported through iterative cycles of reflection and seeking new knowledge to ensure a change in teaching practice as learning outcome. (Timperley, 2008, p. 29). This belief is shared by Williamson (2012) who maintains that the role of intrinsic motivation, when students are motivated to engage in the learning process because it interests them or when they recognise the value of a programme, has greater impact on student learning than extrinsic motivation driven by incentives. In the same way a high motivation for learning demonstrated at the onset of the programme can just as easily change to adversity in cases where teachers are disillusioned with the way a programme supports the development of their applied competence.

\section{Research Method and Theory}

\section{Conceptual Framework}

The conceptual framework for this research is inspired by the model suggested by Shulman and Shulman (2004, p. 268) as a frame for a more comprehensive conception of teacher learning and development in teacher learning communities. While their model of teaching and teacher learning, illustrated as a set of nested polygons, focuses more on the role of teacher education in guiding, deepening, and enhancing the vision teachers have of their own professional development, our concern shifts to the role of motivation resulting from the way teachers experience a DL programme to meet their visions and expectations of the way a programme will support them in their applied competence. This emphasis on the determining role of affective factors in sustained learning outcomes is in accord with sentiments expressed in the literature (Ahmad, Said, Zeb, Sihatullah., \& Ur Rehman, 2013, p. 26; Rodgers, 2002, p. 858; Schieb \& Karabenick, 2011).

We adapted the multi-layered model of Shulman and Shulman by placing the emphasis on the relationship between teachers' expectations and experiences with regard to the programme. This adapted model is based on the assumption that teachers who do not experience a PDP to make a difference in their practice will not be motivated to change or improve their practice as a result of the PDP. In the same way teachers who experience the PDP to meet their expectations and visions will be more motivated to apply new knowledge gained through the programme in a sustainable way in their classrooms.

The core elements of applied competence identified from the literature form part of each layer of the multi-layered conception (Figure 1), namely, improved: i) PCK, ii) self-directedness, iii) applied practice and vi) professional attitude. The inner layer at the core of the model represents the expectations held by teachers regarding the way the programme will support the development of identified core elements of applied competence. The second layer represents the teachers' experiences of the way the programme met their expectations with regard to each of these core elements on the assumption that a strong correlation between expectations (inner layer) and experiences (middle layer) will have a positive impact on the outer layer which represents sustained applied competence as programme outcome. The following figure illustrates this assumption of sustained applied competence grounded in the aligned expectations and experiences of teachers with regard to support for the development of the core elements of applied competence through a DL programme. 


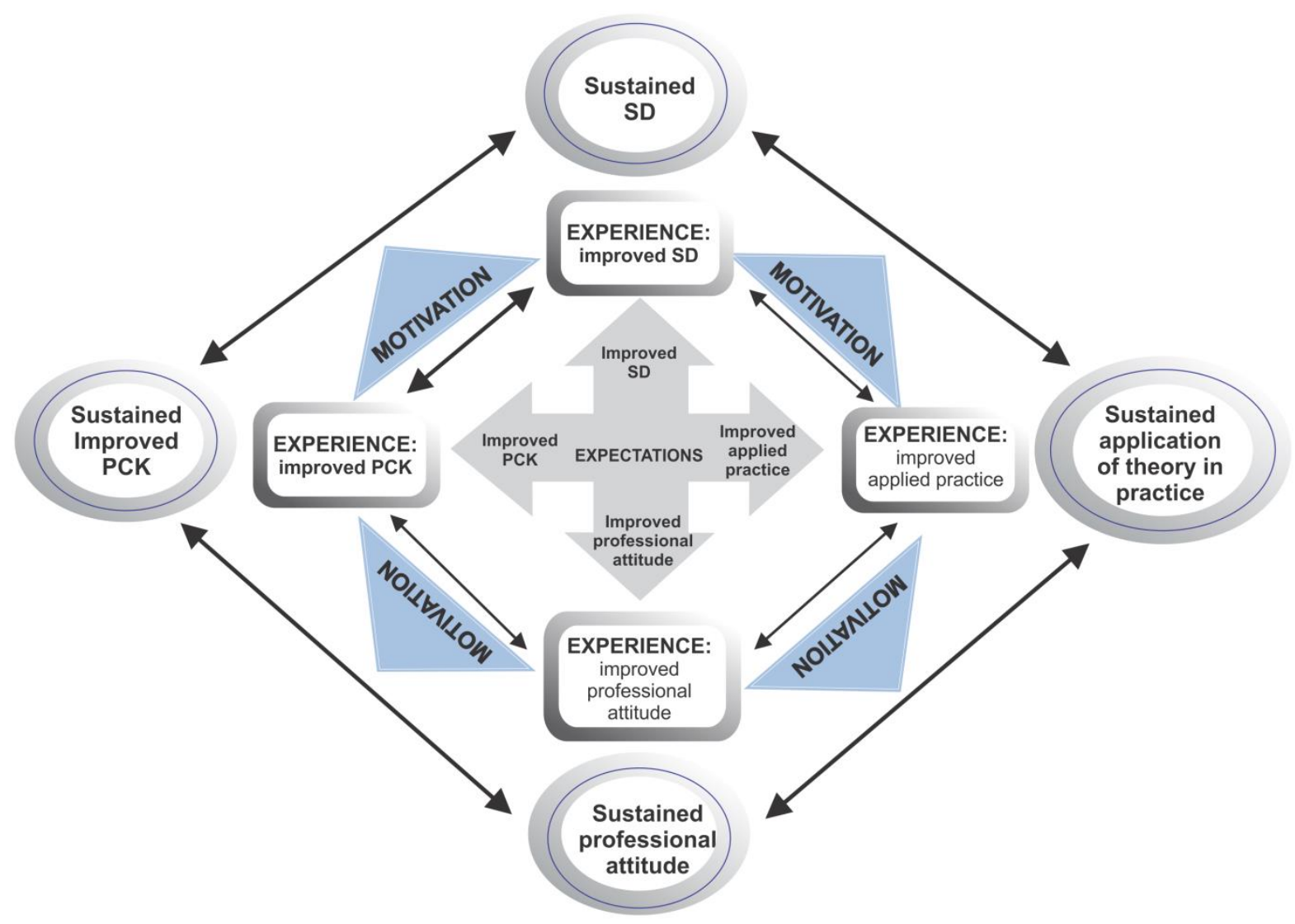

Figure 1. Sustained applied competence model (based on the model by Shulman and Shulman, 2004).

The incapacity of DL programmes to meet the needs of teachers with regard to their applied competence in the South African context is probably one of the reasons for criticism levelled against the use of DL for teacher professional development as debated by Taylor (2013).

Teachers entering a PDP with anticipation that the programme will support them in the development and improvement of their PCK, self-directedness, applied practice, and professional attitude, already recognise a need for professional development. Should the teachers experience the programme to meet these personal expectations it could serve as motivation for learning and applying knowledge in practice.

Shulman and Shulman (2004, p. 261) base their theory of teacher-learning on the argument that a teacher can develop a new vision (expectation) of her own teaching through for instance role models, reading cases, viewing tapes, holding discussions with peers, and reading theoretical accounts, thereby becoming dissatisfied with the status quo (p. 261). The inclusion of visuals on effective practice as part of the DL programme which is the focus of this article was based on this principle and served as a way to support the development of a new vision of teaching based on reflection on effective practice. It was anticipated that this visual resource, together with a work-integrated portfolio, would serve as motivation for teachers to improve their applied competence. 


\section{Research Design}

In accordance to the call made by Schieb and Karabenick $(2011$, p. 8) for research focusing on teacher experiences of PDP relevancy, we specifically set out to determine teachers' expectations for the practical component of a revised PDP as well as their experiences of the way the DL PDP met these expectations (p.8). Grounded in the literature, we anticipated the findings to give us an indication of the value of the programme for sustained applied competence of practicing teachers in their specific teaching context. The researchers believe that congruence between teacher expectations and experiences with regard to the programme could secure applied competence as programme outcome.

The four elements of applied competence identified from the literature, namely, pedagogical content knowledge, self-directedness, a professional attitude, and opportunity for guided application of knowledge in practice, served as categories for the coding of statements about the teachers' expectations and experiences.

Although a strong correlation between expectations and experiences is not a guarantee for programme success, the literature endorses the relationship between teacher motivation and sustainable outcomes. A strong correlation between these aspects could be an indication that the programme meets the professional learning needs of the target teacher population and thus endorses teacher satisfaction, and a weak correlation may be an indication of disillusionment with the way the programme meets the specific learning needs of teachers. Measuring the expectations before the programme against experiences during and after the programme could provide valuable information for programme designers of possible strengths and weaknesses of the design and content. The extent to which a programme meets teacher expectations is believed to be a strong indication of the sustainability of programme outcomes in practice. No studies could be identified that specifically focus on the relationship between expectations and experiences of teachers with regard to a professional development programme in the South African context.

\section{Methodology}

This implementation evaluation study followed an interpretivistic paradigm and intended to develop a deep understanding of the value of a PDP for teachers in their teaching context. The study is grounded in a qualitative research design to determine teacher expectations for the way the programme will support their applied competence, as well as their experiences of the way the programme supported elements of applied competence. Expectations and experiences were then compared in order to determine in which way the revised PDP met the teachers' expectations.

Data was collected before and after implementation of this practical component from a study population consisting of 50 teacher students who were enrolled by the Department of Education as the first of three cohorts in a bursary project. A multiple method design was used to collect data through various methods from willing participants. Through using a wide-range of interconnected interpretive practices, we hoped to get a better understanding of the phenomenon (Denzin \& Lincoln, 2013, p. 7). The following table gives a reflection of the data collection process. 
Table 1

Data Collecting: Samples, Methods, and Instruments

\begin{tabular}{|c|c|c|c|}
\hline & $\begin{array}{l}\text { Implementation } \\
\text { stage }\end{array}$ & Sample & Method \\
\hline \multirow[t]{3}{*}{ Expectations } & \multirow{3}{*}{$\begin{array}{l}\text { Pre- } \\
\text { implementation } \\
\text { (before } \\
\text { implementation of } \\
\text { the practical } \\
\text { component) }\end{array}$} & 39 & $\begin{array}{l}\text { Open-ended questions of semi-structured } \\
\text { questionnaire }\end{array}$ \\
\hline & & 15 & Focus-group discussion \\
\hline & & 15 & $\begin{array}{l}\text { Written expectations for the practice based } \\
\text { component }\end{array}$ \\
\hline \multirow[t]{2}{*}{ Experiences } & \multirow{2}{*}{$\begin{array}{l}\text { Post- } \\
\text { implementation } \\
\text { (after } \\
\text { implementation of } \\
\text { the practical } \\
\text { component }\end{array}$} & 36 & $\begin{array}{l}\text { Open-ended questions of semi-structured } \\
\text { questionnaire }\end{array}$ \\
\hline & & 4 & $\begin{array}{l}\text { Individual interviews on experiences of } \\
\text { learning portfolios }\end{array}$ \\
\hline
\end{tabular}

Through content analyses the four elements of applied competence identified from the literature, namely, pedagogical content knowledge, self-directedness, a professional attitude, and opportunity for guided application of knowledge in practice, served as categories for coding the teachers' expectations and experiences. Using the same categories for coding the qualitative data collected before and after implementation permitted a comparison between teacher expectations and experiences with regard to the four elements of applied competence.

\section{Analysis and Results}

A network compiled trough ATLASti ${ }^{\mathrm{TM}}$ allowed us to identify and compare codes related to expectations for the way the programme will support elements of applied competence, with participants' experiences of the way the programme supported these elements (Figures 2 to 4). In Figure 2 the codes related to expectations are indicated with an exclamation mark - [!], while in Figure 3 the codes related to experiences are indicated with a hash [\#]. These networks created through ATLASti ${ }^{\mathrm{TM}}$ reflect the total number of quotations linked to expectations and experiences with regards to the four core elements of applied competence. Therefore it is not reported as definite outcomes of the programme but indications of the way the programme met the teachers' expectations based on quotations collected before and after the programme implementation.

Quotations reflecting teacher expectations for the way the programme will support their knowledge $(n=85)$ and improve their teaching practice $(n=66)$ showed higher than the number of quotations linked to expectations for improved self-directedness $(n=46)$ and improved professional attitude $(n=18)$ (Figure 2). 


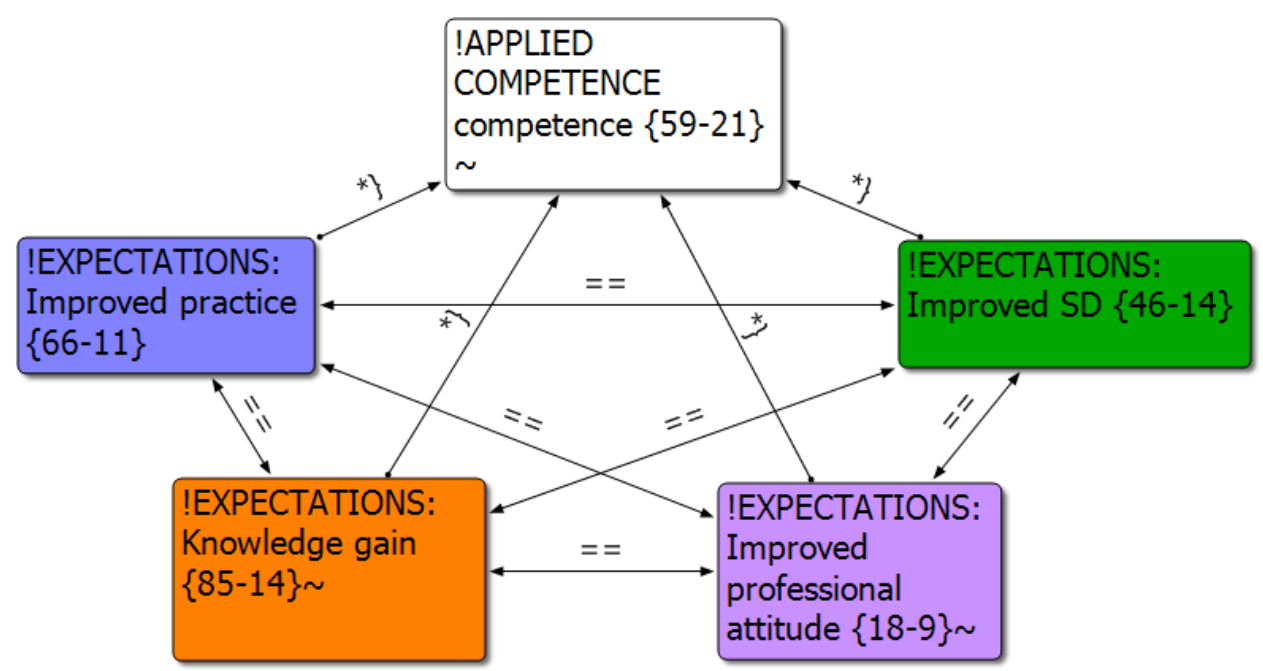

Figure 2. Expectations for the way the programme will support applied competence.

However, this picture changes for quotations linked to experiences (Figure 3) where the higher number of quotations could be linked to codes reflecting experiences of improved self-directedness $(n=103)$ and experiences of improved professional attitude $(n=68)$. Experiences of improved practice $(n=52)$ and improved PCK $(n=62)$ reflect somewhat lower than the number of quotations linked to expectations for these two core elements through the programme.

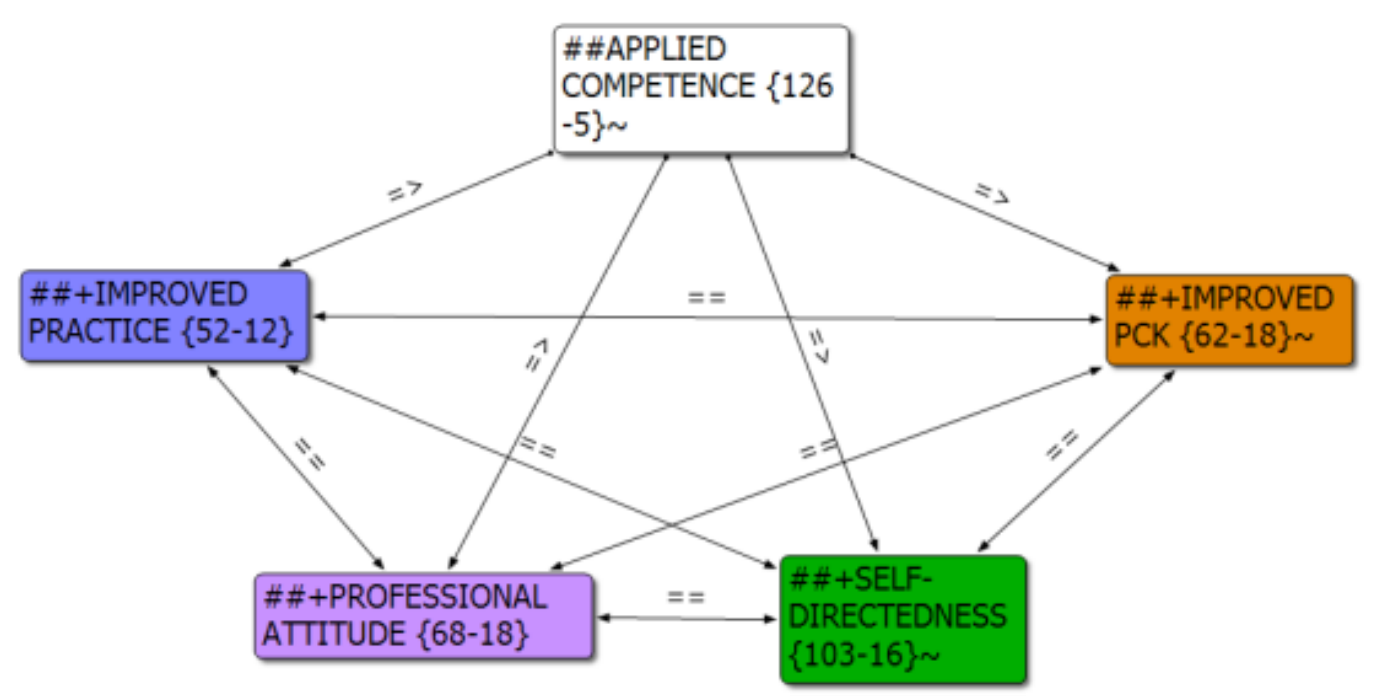

Figure 3. Experience of the way the programme supported applied competence.

Although code frequencies related to experiences (\#) of improved practice and improved knowledge are slightly lower than the correlating expectations (!) for these competences, the network indicates a relatively good correlation between expectations and experiences with regard to these elements of applied competence (Figure 4). However, there is a significant difference between expectations for improved professional attitude $(\mathrm{n}=18)$ and the participants' experiences of the way the programme supported this element $(n=68)$ and an even larger discrepancy between expectations for improved self-directedness $(n=46)$ and experiences of the way the programme supported participants in this regard $(n=103)$. 


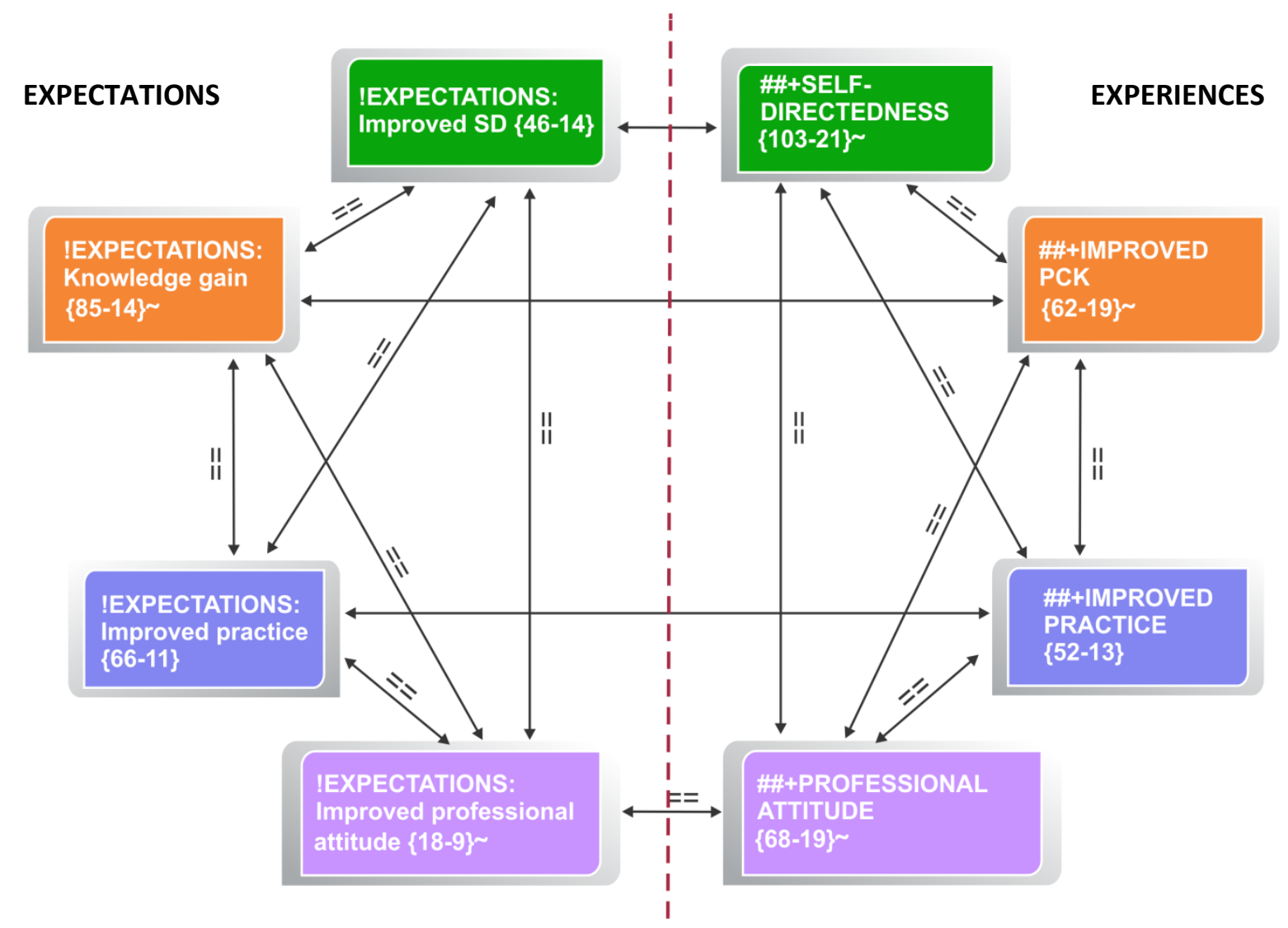

Figure 4. Comparing expectations with experiences with regards to core elements of applied competence.

Reasons for the higher frequency of links to expectations for knowledge gain through the programme as well as for guided application of knowledge in practice may be ascribed to the current dilemma of teachers who are often blamed for their poor subject knowledge (NEEDU, 2013, p. 8; South African Department of Basic Education, 2011, p. 108; Taylor, 2013).

The low number of quotations linked to expectations for the development of a professional attitude may be ascribed to this criterion being overshadowed by more critical developmental needs, or that teachers do not view professional attitude as a PDP aim. However, the increase in the number of quotations linked to the teachers' experiences of the way the programme supported them in developing a professional attitude may be of significance, since the literature highlights the critical role of teacher professional attitude in sustainable applied competence as programme outcome. Reasons for this higher frequency may be ascribed to the way the practical component included visual inserts modelling effective practice, while the working-integrated portfolio guided teachers in the reflective application of knowledge in a professional way in practice.

The even larger discrepancy between expectations for improved self-directedness $(n=46)$ and experiences of the way the programme supported participants in this regard $(n=103)$ may also indicate a new awareness of critical teaching competences such as reflection and inquiry. The working portfolio specifically required teachers to continuously reflect on their practice and to use these reflections to improve their teaching strategies. Where reflection as part of self-directedness is 
frequently cited as one of the most dominant outcomes of the portfolio process (eg Brown, 2001; Chetcuti, Buhagiar, \& Cardona, 2011; Darling-Hammond \& Snyder, 2000; Du, 2013; Isoré, 2009; Orland-Barak, 2005; Shulman, 2003, to name but a few), this high number of quotations linked to experiences of improved self-directedness serves as a strong confirmation of the value of the portfolio as part of a DL programme for teacher professional development.

\section{Conclusion}

The findings show a strong correlation between teacher expectations and experiences with regards to identified core elements of applied competence. Furthermore, quotations collected from teachers after the programme showed surprisingly high experiences of the way the programme supported the development of self-directedness and an improved professional attitude through the programme.

Since DL is viewed as a viable and cost effective way to improve teacher competence in developing countries, these findings serve as motivation for further investigations into the most viable ways to include work-integrated portfolios in DL PDPs. Although this case study investigated the expectations and experiences of a small sample of teachers in one province of South Africa, the findings may be meaningful for PDP designers in other developing countries who are also looking for ways to support applied competence of teachers through DL programmes.

The literature highlights the importance of alignment between teacher expectations and teacher experiences with regards to the development of their applied competence (Schieb \& Karabenick, 2011; Shulman \& Shulman, 2004). The findings may be a meaningful indicator of the value of a practical component as part of a PDP delivered via DL. Based on related literature, it is predicted that a programme which lives up to teachers' expectations will not only improve their commitment but will serve as motivation to apply new knowledge and skills in sustained ways in practice. The correlation between expectations and experiences which is evident in the findings strongly suggests that teachers will be more motivated to apply new knowledge gained through the programme in practice. However, the true sustainability of improved applied competence as a result of the practical component requires further investigation.

Teachers should experience a programme to be of value if it equips them to overcome challenges posed by their specific teaching contexts. In order to turn the current poor standard of education around, teachers do not only need to acquire the subject knowledge they lack, but they also require a change in their vision of what effective teaching and learning entails. Changing the vision of teachers based on critical reflection, not only of their own practices but also that of others, by means of visual resources in a PDP will contribute to the transformation of educational standards through improved applied competence. The following quote by a participant clearly illustrates a changed vision as a result of the programme:

The portfolio has open my eyes and now I can look at my learners with learning barriers with positive attitude [...] Prior this programme I was very much frustrated I even put them aside cause I just didn't have the knowledge and tip of dealing with them. Thank you very much! [sic] (Post-implementation semi-structured questionnaire). 


\section{Recommendations}

A major frustration for teachers who want to make a difference in the learning of their learners is when they do not have the knowledge, the tools, or the support to engage effectively with their learners (Timperley, Wilson, Barrar, \& Fung, 2007, p. xiii). Meeting the professional learning needs of teachers in a PDP plays a critical role in motivating teachers to apply knowledge in practice which in turn plays a determining role in sustainable applied competence. PDPs should therefore not only make the proverbial "tick in the box" by supplying theoretical knowledge to teachers but also ensure that teachers experience the programme to support the professional development needs experienced by them in their specific teaching contexts. Teachers should therefore play a participative role in programme design and designers should hear the voice of the teachers with regards to their specific professional learning needs.

Furthermore, PDPs aiming to contribute to the transformation of South Africa's education standards should include design features that support teachers to link theoretical knowledge to their specific practice, and guide reflection on and in practice. Based on these reflections, teachers should be guided to find solutions to teaching challenges and to make informed choices in their specific teaching contexts. Such an accountable approach to teaching will further support the development of a professional attitude, which drives transformation in education.

\section{References}

\section{References}

Ahmad, I., Said, H., Zeb, A., Sihatullah., \& Ur Rehman, K. (2013). Effects of professional attitude of teachers on their teaching performance: Case of Government Secondary School teachers in Malakand Region, Khyber Pakhtunkhwa, Pakistan. Journal of Educational and Social Research, 3(1), 25-31. doi:10.5901/jesr.2013.v3n1p25

Beaudin, B. P., \& Quick, D. (1995). Experiential learning: Theoretical underpinnings (ETT-95-02). Retrieved from http://users.ugent.be/ mvalcke/LI 1213/experiencial learning.pdf

Berrill, D. P., \& Addison, E. (2010). Repertoires of practice: Re-framing teaching portfolios. Teaching and Teacher Education, 29, 1178-1185. Retrieved from http://ac.elscdn.com/So742051X10000247/1

Binns, F., \& Wrightson, T. (2006). Teacher education at a distance: Impact on development in the community. Researching the Issues, 64, 60. Retrieved from http://www.mtnforum.org/sites/default/files/publication/files/1881.pdf

Brown, J. O. (2001). The portfolio: A reflective bridge connecting the learner, higher education, and the workplace. The Journal of Continuing Higher Education, 49(2), 2-13. doi:10.1080/07377366.2001.10400426

Boud, D., Keogh, R., \& Walker, D. (1996). Promoting reflection in learning - A model. In R. Edwards, A. Hanson, \& P. Raggatt (Eds.), Boundaries of adult learning (pp. 32-56). London: Routledge. 
Chetcuti, D., Buhagiar, M. A., \& Cardona, A. (2011). The professional development portfolio: Learning through reflection in the first year of teaching. Reflective Practice, 12(1), 61-72. Retrieved from http://www.tandfonline.com/doi/pdf/10.1080/14623943.2011.541095

Daniel, J. (2010, March). Distance education: Ends, means, opportunities, threats. Paper presented at the The Aga Khan Development Network - Higher Education Forum, Vancouver, BC.

Darling-Hammond, L. (2010). Teacher education and the American future. Journal of Teacher Education, 61(1-2), 35-47. doi:10.1177/0022487109348024

Darling-Hammond, L., \& Snyder, J. (2000). Authentic assessment of teaching in context. Teaching and Teacher Education, 16, 523-545.

Denzin, N. K., \& Lincoln, Y. S. (2013). Introduction: The discipline and practice of qualitative research. In N. K. Denzin \& Y. S. Lincoln (Eds.), The landscape of qualitative research (4th ed., pp. 632). Thousand Oaks: SAGE Publications.

Dewey, J. (1916). Democracy and education: An introduction to the philosophy of education. New York: The MacMillan Company.

Dewey, J. (1933). How we think: A restatement of the relation of reflective thinking to the educative process. Boston: D. C. Health \& Co.

Dewey, J. (1938). Experience and Education. New York: Collier Books.

Du, F. (2013). Student perspectives of self-directed language learning: Implications for teaching and research. International Journal for the Scholarship of Teaching and Learning, 2(2). Retrieved from http://digitalcommons.georgiasouthern.edu/ij-sotl/vol7/iss2/24

Farr Darling, L. (2001). Portfolio as practice: The narratives of emerging teachers. Teaching and Teacher Education, 17, 107-121. Retrieved from http://ac.elscdn.com/So742051X0000041X/1

Ferlazzo, L. (2012). Eight things skilled teachers think, say, and do. Educational Leadership, 7o(2). Retrieved from http://www.ascd.org/publications/educational

Granlund, R., Berglund, E., \& Erikson, H. (2000). Designing web-based simulation for learning. Future Generation Computer Systems, 17, 171-185.

Imhof, M., \& Picard, C. (2009). Views on using portfolio in teacher education. Teaching and Teacher Education, 25, 149-154.

Isoré, M. (2009). Teacher evaluation: Current practices in OECD countries and a literature review. Retrieved from http://dx.doi.org/10.1787/223283631428

Kansanen, P. (2006). Constructing a research-based program in teacher education. In F. K. Oser, F. Achtenhagen, \& U. Renold (Eds.), Comptence oriented teacher training - Old research demands and new pathways (pp. 11-22). Rotterdam, The Netherlands: Sense Publishers. 
Klenowski, V. (2002). Developing portfolios for learning and assessment. Abingdon:

RoutledgeFalmer.

Klenowski, V., Askew, S., \& Carnell, E. (2006). Portfolios for learning, assessment and professional development in higher education. Assessment \& Evaluation in Higher Education, 31(3), 267286. doi:10.1080/02602930500352816

Ley, K. (2005). Motivating the distant learner to be a self-directed learner. Paper presented at the 2oth Annual Conference on Distance Teaching and Learning.

Lobman, C., Ryan, S., McLauchlin, J., \& Ackerman, D. (2004). Educating preschool teachers: Mapping the teacher preparation and professional development system in New Jersey. Retrieved from http://www.fcd_doc/EducationPreschoolTeachers.pdf

National Education Evaluation and Development Unit. (2013). National Report 2012: Summary. Pretoria, South Africa. Retrieved from http://www.saqa.org.za/docs/papers/needu.pdf

Oolbekkink-Marchand, H. W., Van Driel, J. H., \& Verloop, N. (2006). Secondary and University teachers' perspectives on self-regulated learning. In F. K. Oser, F. Achtenhagen, \& U. Renold (Eds.), Competence oriented teacher training (pp. 219-234). Rottterdam, The Netherlands: Sense Publishers.

Opfer, V. D., \& Pedder, D. (2011). Conceptualizing teacher professional learning. Review of Educational Research, 81(3), 376-407. doi:10.3102/0034654311413609

Orland-Barak, L. (2005). Portfolios as evidence of reflective practice: what remains 'untold'. Educational Research, 47(1), 25-44. Retrieved from http://www.tandfonline.com/doi/pdf/10.1080/0013188042000337541

Perraton, H., Creed, C., \& Robinson, B. (2002). Teacher education guidelines using open and distance learning: Technology, curriculum, cost, evaluation. Retrieved from http://unesdoc.unesco.org/images/o012/001253/125396e.pdf

Rodgers, C. (2002). Defining reflection: Another look at John Dewey and reflective thinking. Teachers College Record, 104(4), 842-866. doi:016-4681

Rowntree, D. (1992). Exploring open and distance learning. London: Routledge-Falmer.

Sandberg, A., Anstett, S., \& Wahlgren, U. (2007). The value of in-service education of quality in preschool. Journal of In-service Education, 33(3), 301-319. doi:10.1080/13674580701486929

Schieb, L. J., \& Karabenick, S. A. (2011). Teacher motivation and professional development: A guide to resources: University of Michigan, Ann Arbor, MI.

Schön, D. (1983). The reflective practitioner: How professionals think in action. New York: Basic Books.

Shulman, L. S. (1987). Knowledge and teaching: Foundations of the new reform. Harvard Educational Review, 57(1), 1-22. 
Shulman, J. H. (2003). From practice to theory and back again: Cases and portfolios as instruments for professional development. Paper presented at the Annual meeting of the American Educational Research Association, Chicago, IL. Retrieved from http://www.wested.org/nbnetwork/resources/aera 2003 shulman.doc

Shulman, L. S., \& Shulman, J. H. (2004). How and what teachers learn: A shifting perspective. Journal of Curriculum Studies, 36(2), 257-271. Retrieved from http://www.peaunesco.com.br/encontro2013/SHULMAN How\%20and\%20What\%20Teach ers\%20Learn (JrCurriculumStudies 2004).pdf

Siaciwena, R. (2007). The use of open and distance learning in teacher education in the SADC region: Issues and challenges. Paper delivered at the inauguration of the NWU School of Continuing Teacher Education. North-West University. Potchefstroom.

South African Department of Basic Education. (2011). Action plan to 2014 - towards the realisation of schooling 2025. Retrieved from http://www.education.gov.za

South African Departments of Basic Education and Higher Education and Training. (2011). Integrated strategic planning framework for teacher education and development in South Africa, 2011 - 2025. Retrieved from http://www.info.gov.ac.za

Stoll, L., Fink, D., \& Earl, L. (2003). It's about learning (and it's about time). London: RoutledgeFalmer.

Taylor, N. (2013). The state of our education system. PolitcsWeb, 2014. Retrieved from http://www.politicsweb.co.za

Taylor, N. (2013). National Report 2012: The state of literacy teaching and learning in the foundation phase. Retrieved from http://www.shineliteracy.org.za/wpcontent/uploads/2015/11/NEEDU-Report.pdf

Timperley, H. (2008). Teacher professional learning and development. In J. Brophy (Ed.), Educational practices series: Vol. 18. international academy of education (pp. 32). Retrieved from http://www.curtin.edu.au/curtin/dept/smec/iae

Timperley, H., Wilson, A., Barrar, H., \& Fung, I. (2007). Teacher professional learning and development, best evidence synthesis iteration [BES] (pp. 291). Retrieved from http://educationcounts.edcentre.govt.nz/goto/BES

Tsai, C. (2007). Teachers' scientific epistemological views: The coherence with instruction and students' views. Science Education, 92(2), 21. doi:10.1002/sce.20175

Van Driel, J. H., \& Berry, A. (2012). Teacher professional development focusing on pedagogical content knowledge. Educational Researcher, 41(1), 26-28. doi:10.3102/0013189X11431010

Vreugdenhil, K. (2005). Bridge between theory and practice. In H. N. D. Springate (Ed.), Occasional Papers (pp. 119-126). London: University of Greenwich. 
Williamson, R. (2012). Importance of high expectations. Education Partnerships Incorporated.

Retrieved from http://www.educationpartnerships.org

Wray, S. (2007). Teaching portfolios, community, and pre-service teachers' professional development.

Teaching and Teacher Education, 23, 1139-1152. Retrieved from http://ac.els-

cdn.com/So742051X06001545/1

Yasin, R. M., Rahman, S., \& Ahmad, A. R. (2012). Framework for reflective learning using portfolios in pre-service teacher training. Procedia - Social and Behavioral Sciences, 46, 3837-3841. Retrieved from www.sciencedirect.com

Zimmerman, B. J. (2002). Becoming a self-regulated learner - an overview. Theory into practice, 41(2), 64-70. 